being at least, be carried out under more centralized administration. The present act retains the USHA-local authority organization, but it clearly shifts the initiative from the local to the federal authority. The condemnation power is placed in the Federal Government, the slum elimination requirement is dispensed with, and no tax exemption is required. ${ }^{\text {III }}$ It does not appear, however, that this shift in control arose from any particular discontent with the decentralized administration; it is probably only a recognition that where emergency building is concerned the Federal Government can operate more efficiently in a direct manner than through local authorities. Where, however, public housing is viewed as a part of the attack on the whole housing problem, the prevalent opinion is that housing is a local problem, best undertaken by local authorities. .r2 $^{\text {Ir }}$ Demolition of buildings, city planning, zoning, and real estate taxation are all local problems; and if, as appears to be the case, public housing must be carried on in cooperation with government activities in these fields, then public housing is likewise a local problem.

Moreover, while the federal power of eminent domain for housing is a constitutional exercise of authority under the war power, it has not been upheld under non-emergency conditions. ${ }^{113}$ The denial of the power by the circuit court of appeals in United States $v$. Certain Lands in Louisville ${ }^{\mathrm{rr} 4}$ was one of the reasons for the decentralization of the housing program in I937; and until the issue is decided otherwise by the Supreme Court, ${ }^{\text {IIs }}$ the doubt that exists might in itself be sufficient to thwart the use of the centralized program under non-emergency conditions. ${ }^{116}$

\title{
THE BERTRAND RUSSELL LITIGATION
}

On February 26, I940, the Board of Higher Education of New York City by unanimous vote appointed Bertrand Russell as Professor of Philosophy in the

Irx H.R. 9822, June 28, 1940 (Pub. No. 67r).

${ }_{\text {II2 }}$ Walker, Urban Blight and Slums 350 (r938); [ r939] Annual Rep. U.S.H.A. II; Metropoli$\tan$ Housing Council, Where Are We in Public Housing? 9 (I937). But see Laski, The American Presidency 25x (1940): "Whether the issue is the unemployed or housing, public utilities like railroads and electric power, the position of the farmer, the place of trade unions in society, the level and methods of taxation, they are insoluble problems if they are met in a sectional way. Their range and intensity will compel the political parties more and more to confront them nationally."

${ }_{2 \times 3}$ Eminent domain for housing might conceivably be based on the war power even under non-emergency conditions. See statement of Harold Ickes (Report of House Committee on

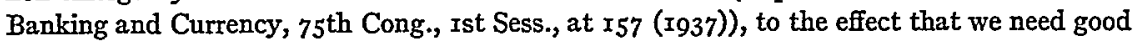
housing at all times in order to have the kind of men who can defend the nation.

${ }^{2 \times 4} 78$ F. (2d) 684 (C.C.A. 6 th 1935 ).

rrs The United States Supreme Court granted certiorari in United States v. Certain Lands in Louisville, 78 F. (2d) 684 (C.C.A. 6 th 1935 ), but the government obtained a dismissal a few hours before the case was to be argued. See Ebenstein, Law of Public Housing 44-46 (I940).

${ }^{x 16}$ There may be some significance, however, in the fact that whereas each section of Title I of the Act (note III supra) is stated to be an emergency measure, there is no mention of an emergency in Title II, which deals with public housing. 
College of the City of New York, ${ }^{,}$thus precipitating a major public controversy ${ }^{2}$ centering about Russell's views on morals and the unconventional details of his personal life. ${ }^{3}$ Taking cognizance of this discussion, the board announced on March 7 that it would reconsider its decision, and on March I8, after considering the objections that had been raised, voted eleven to seven to uphold the appointment. On the same day a suit was filed in the Supreme Court of New York County asking for an order reviewing the action of the board and rescinding the appointment.4

The petition contended that the appointment violated a section of the Education Law of New York prohibiting the employment of aliens in public schools, ${ }^{s}$ and was contrary to public policy on the ground that Russell's views (as expressed in some of his writings) constituted an influence dangerous to the morals and welfare of students of City College. The assistant corporation counsel, representing the board, moved to dismiss the petition as failing to state facts suffcient to constitute a cause of action, but he argued only the question of citizenship. An additional point not included in the petition was raised at the hearing by counsel for petitioner, who contended that the appointment violated that provision of the state constitution requiring that appointments to civil service positions be preceded, where practicable, by competitive examinations. ${ }^{6}$ The court, without ruling on the motion to dismiss, directed petitioner's counsel to introduce his evidence. 7 Three days later an opinion was rendered based primarily upon this brief hearing and a "consideration" by the presiding justice of

× The College of the City of New York is an institution supported by public funds under the administration of the Board of Higher Education. The powers of such boards are set forth in Section $x 143$ of the Education Law, N.Y. Cons. Laws (McKinney, I938) c. x6. These boards must be distinguished from boards of education which are responsible for primary and secondary schools.

${ }^{2}$ The controversy attracted nation-wide attention. Prominent churchmen, and patriotic and fraternal organizations decried the appointment. Scientists, educators, writers and philosophers came to Russell's defense. It was inevitable that the case should become a political issue, and on April 6, Mayor La Guardia announced that the provision in the city budget for Russell's professorship had been eliminated. On April 24, a resolution was adopted by the city's Board of Estimate imposing as a condition governing the expenditure of funds appropriated in the $x 94^{\circ}-4 x$ budget the provision that no funds be used for the future employment of Bertrand Russell. Numerous resolutions were introduced in the City Council and the state legislature, ultimately leading to the formation of the Rapp-Coudert Committee, currently investigating New York's municipal colleges.

3 Russell has, on various occasions, advocated freer relations between the sexes, and has been divorced on grounds of adultery.

4 The suit was a proceeding under Article 78 of the Civil Practice Act filed by Mrs. Jean Kay, a Brooklyn housewife.

${ }_{5}$ N.Y. Cons. Laws (McKinney, I938) c. $16, \S 55^{\circ}$. $\quad{ }^{6}$ N.Y. Const. art. $5, \S 6$.

7 As a result of this seemingly irregular procedure, a trial on the merits was held without an answer having been filed. The court contended that the assistant corporation counsel had declined to file an answer; this the latter denied, and he informed Russell's attorney that he supposed that until the motion to dismiss was decided the question of answering did not arise. 
four of Russell's books. ${ }^{8}$ The court denied the motion to dismiss because only one of petitioner's grounds had been contested, upholding all three of petitioner's contentions. The court admitted, however, that the "compelling" reason for nullifying the appointment was the "moral" one.9 It found as a matter of fact ${ }^{\mathrm{xO}}$ that the board had not investigated Russell's fitness, that Russell was not a person of good moral character, and that his views would tend to encourage violation of the Penal Law of New York.

On April I Russell retained counsel, ${ }^{x x}$ who on the following day filed a motion in his client's behalf for leave to intervene as a party to the proceeding, and for permission to serve an answer. The order denying this motion ${ }^{12}$ was affirmed by the appellate division on May $24,{ }^{13}$ and on June ${ }^{4} 4$ leave to appeal to the Court of Appeals was denied. ${ }^{\mathrm{I}}$ The corporation counsel having decided not to assist in an appeal because of fear that moral and religious predilections would confuse the fundamental issues of law, ${ }^{\mathrm{x}}$ the board retained independent counsel. Its right to be represented by such counsel was denied, ${ }^{16}$ and its appeal and the separate appeal of a majority of the board from an order denying their right to intervene as individuals were dismissed by the appellate division on June $19 .{ }^{x 7}$ Finally, on October 8 the New York Court of Appeals denied Russell's motion for leave to appeal on the ground that the order appealed from-that refusing him the right to intervene-was not a final order. ${ }^{18}$

${ }^{8}$ What I Believe (I925); Education and the Good Life (I926); Marriage and Morals (I929); Education and the Modern World (1932). Unread by Mr. Justice McGeehan was Russell's Principles of Mathematics (IgO3).

The court also had before it minutes of the two meetings regarding the Russell appointment held by the Board of Higher Education. The court allowed amici curiae to introduce briefs but refused to permit them to argue orally on the "morals" question.

9 Matter of Kay v. Board of Higher Education, $x 73$ Misc. 943,947 , 18 N.Y.S. (2d) 821, 826 (S. Ct. I940).

ro The findings of fact and the final order were dated April 17 , I940.

Ix During these proceedings Russell was in California teaching at the University of California at Los Angeles. Russell had previously taught at Cambridge, Chicago, Harvard, Oxford, and Smith.

I2 The denial was made on the ground that Russell was guilty of inexcusable laches in making his application and that he was not a necessary party to the proceedings. In view of the unusual dispatch shown by the court, which denied the motion to dismiss, heard and granted the petition, rendered a decision, and wrote a lengthy opinion-all in the space of three daysit seems far from apparent that Russell delayed unduly in asking for leave to intervene. The court indicated that Russell must have been fully informed since his attorney had first appeared in court as an amicus curiae. But the position of an amicus curiae as an impartial aid to the court excludes him from any partisan function.

${ }^{13} 259$ App. Div. 879, 20 N.Y.S. (2d) I0I6 (r940).

14259 App. Div. 1000, 2 I N.Y.S. (2d) 396 (I940).

Is See letter of Corporation Counsel Chanler, N.Y. Times col. I, p. 25 (April I7, I940).

${ }^{26} \mathrm{New}$ York City Charter $\S 394$ (a) provides that the corporation counsel shall be counsel for the city and every agency thereof. Section 395 lists the exceptions to this requirement.

${ }^{77} 260$ App. Div. 9, 20 N.Y.S. (2d) 898 (I940).

${ }^{28} 284$ N.Y. IO, 29 N.E. (2d) 657 (r940). 
The Bertrand Russell litigation raises at least two fundamental questions. First, has a court the power to void the appointment of an individual to the faculty of an institution supported by public funds merely because of that individual's opinions? ${ }^{29}$ Second, assuming that power, has the person whose opinions are under examination the right to intervene in order to defend himself?

I

The original proceedings were instituted under Article 78 of the Civil Practice Act, which provides for the granting of relief against public bodies formerly obtainable by the writs of certiorari, mandamus, and prohibition..$^{\circ}$ It has been suggested that the remedy sought here could not have been granted under any of these writs, and therefore cannot be obtained under the present statute. ${ }^{2 x}$ Moreover, it is doubtful whether the petitioner had a sufficient interest in the action of the board to institute this proceeding. ${ }^{22}$ In any event, there would appear to be an insuperable obstacle to the maintenance of this suit. Section II 46 of the Education Law of New York states that no action or special proceeding shall be brought against the Board of Higher Education, for any cause whatever, unless the complaint alleges that the demand upon which the action or proceeding is founded was presented to the board for adjustment at least thirty days before the bringing of the action or proceeding, and that the board had neglected or refused to make an adjustment during that period. ${ }^{23}$ The petitioner's complaint contains no such allegation, and indeed it could not, since thirty days had not elapsed between Russell's appointment and the filing of the complaint. Under Article 78 relief is excluded where the petitioner could have sought a rehearing and has made no attempt to do so. ${ }^{24}$

The substantive objections to Russell's appointment found by the court were: (I) as an alien Russell was ineligible for this appointment; (2) his fitness had not been ascertained by means of a competitive examination; and (3) although good moral character was an essential qualification for teachers in schools

${ }^{19}$ See the letter of Chancellor Chase of New York University to the N.Y. Times, col. 7, p. I6 (April 20, 1940).

${ }^{20}$ N.Y. Civ. Prac. Ann. (Gilbert-Bliss, Supp. I940) § 1283 .

${ }^{2 x}$ For a discussion of this aspect of the case, see The Bertrand Russell Case: The History of a Litigation, 53 Harv. L. Rev. II92, II95-96 (I940).

22 Ibid. at rr95. This has been widely regarded as a taxpayer's suit, but it is not clear that it was so intended. Had it been intended as a taxpayer's suit it would probably have been filed under Section 5 I of the General Municipal Law. N.Y. Cons. Laws (McKinney, Igr7) c. 24, $\$ 5$ r. Suits under this section will lie to restrain an illegal act tending to produce public injury or mischief or to dissipate public funds. Campbell v. City of New York, 244 N.Y. 3 I7, I55 N.E. 628 (I927); Hathaway v. Oneonta, I48 Misc. 695, 266 N.Y. Supp. 237 (S. Ct. I933); Altschul v. Ludwig, 216 N.Y. 459, III N.E. 216 (IgI6). The payment of a salary in violation of law has been held to constitute such waste. Schiefielin v. Lahey, I22 Misc. 358, 204 N.Y. Supp. r20 (S. Ct. I924); Barlow v. Craig, 2I0 App. Div. 7r6, 206 N.X. Súpp. 293 (I924).

${ }^{23}$ N.Y. Cons. Laws (McKinney, I938) c. I6, \$ $1 \mathrm{r} 46$.

${ }_{24}^{4}$ N.Y. Civ. Prac. Ann. (Gilbert-Bliss, Supp. 1940) § I285(5). 
supported by public funds, the board had made no investigation of Russell's moral character-which the court found was not good.

Section $55^{\circ}$ of the Education Law, prohibiting the appointment of aliens, was deemed applicable to appointments made by the Board of Higher Education. It is arguable, however, that the broad language of an amendment to the Education Law authorizing boards of higher education to waive the citizenship requirement was intended to cover appointments to teaching positions as well as the admissibility of students. ${ }^{25}$ Under such an interpretation this provision limits the scope of a prior amendment which attempted to incorporate by reference into the section dealing with boards of higher education provisions relating to appointments found elsewhere in the Education Law. ${ }^{26}$ This latter amendment indicates an assumption by the legislature that provisions applicable to public schools did not apply to institutions administered by boards of higher education. Apart from this consideration, there is sufficient internal evidence to indicate that Section 550 applies only to teachers in elementary and secondary schools. ${ }^{27}$ And further, a proviso in the section prevents its application if, within a reasonable time, the teacher files declaration of intention to become a citizen. ${ }^{28}$ The holding that Russell would be denied citizenship on moral grounds should he apply seems to be an attempt by the court to circumvent this qualification by passing on a question beyond its powers to decide.

The New York Constitution requires that fitness for civil service appointments be ascertained "so far as practicable by examinations, which, so far as practicable, shall be competitive." ${ }^{\prime 29}$ The legislature, or the appropriate admin-

${ }^{25}$ N.Y. Cons. Laws (McKinney, I938) c. $x 6, \S \mathrm{II43-b.}$

${ }^{26}$ This attempted incorporation by reference was declared unconstitutional in Matter of Becker v. Eisner, 277 N.Y. $x_{43}, I_{3}$ N.E. (2d) 747 ( $x_{93} 8$ ).

${ }_{27}$ Article 20 of the Education Law, which includes Section $55^{\circ}$, does not mention boards of higher education, and many of its provisions seem clearly inapplicable to college teachers.

28 "No person shall be employed or authorized to teach in the public schools who is: . . . 3 . Not a citizen. The provisions of this subdivision shall not apply, however, to an alien teacher now or hereafter employed, provided such teacher shall make due application to become a citizen and thereafter within the time prescribed by law shall become a citizen." N.Y. Cons. Laws (McKinney, x938) c. I6, $\$ 55^{\circ}$.

${ }^{29}$ N.Y. Const. art. $5, \S 6$. The Civil Service Law was adopted pursuant to this provision of the constitution. See Matter of Craig v. Board of Education, x 73 Misc. 969,979 , I 9 N.Y.S. (2d) 293, 302 (S. Ct. I940); Palmer v. Board of Education, 250 App. Div. 362, 364, 294 N.Y. Supp. 92,94 (1937). It provides that "the 'civil service' of the state of New York or any of its civil divisions or cities includes all offices and positions of trust or employment in the service of the state or of such civil division or city...." N.Y. Cons. Laws (McKinney, I940) c. 7, § 2(3). The civil service of the state is divided into unclassified and classified services, and persons employed in the public service as teachers in a college are placed in the unclassified service. The civil service commissioners have no jurisdiction over the unclassified service. See Matter of Craig v. Board of Education, 173 Misc. 969 , I9 N.Y.S. (2d) 293 (S. Ct. x940). The presumption with regard to the unclassified service is that determination of fitness by examination is not practicable. See Matter of Carow v. Board of Education, 272 N.Y. 34I, 347, 6 N.E. (2d) 47,50 (1936). The state legislature established the Board of Higher Education of the City 
istrative agency, has discretion to determine the question of practicability. ${ }^{30}$ This discretionary power to exempt positions from competitive examinations must be used reasonably; ${ }^{31}$ it should be interfered with only when exercised in a "palpably illegal" manner. ${ }^{32}$ It might be argued that the practice of the Board of Higher Education in not requiring competitive examinations for professorial appointments ${ }^{33}$ is equivalent to a ruling that such examinations are impracticable. The criterion employed by the courts in determining practicability is the nature and duties of the position itself. ${ }^{34}$ The practical difficulties involved in formulating and giving examinations for college or university faculty positions are readily apparent. ${ }^{35}$ In this instance, moreover, the board was seeking not simply to appoint a professor of philosophy, but to secure the services of Bertrand Russell because of his eminence as a philosopher. When a college or university, after study of the available candidates, invites an outstanding scholar to teach, a competitive examination is manifestly impracticable. ${ }^{36}$

The court characterized the action of the board as arbitrary, capricious, and in direct violation of the public health, safety, and morals, asserting that the appointment of teachers of bad moral character was contrary to public policy. ${ }^{37}$

of New York to administer the city's colleges, and specifically delegated upon that agency the power to appoint teachers. N.Y. Cons. Laws (McKinney, x940) c. I6, \& II43.

${ }^{30}$ See People ex rel. Merritt v. Kraft, I45 App. Div. 662, 664, I3० N.Y. Supp. 363, 364 (I9II); People ex rel. Schau v. McWilliams, 185 N.Y. 92, 99, 77 N.E. 785, 787 (1906); Matter of Ottinger v. Civil Service Com'n, 240 N.Y. 435, 440, I48 N.E. 627, 628 (I925); Matter of Andresen v. Rice, 277 N.Y. 27I, 276, $1_{4}$ N.E. (2d) 65,67 (I938); Matter of Craig v. Board of Education, I7 Misc. 969, 979, I9 N.Y.S. (2d) 293, 303 (S. Ct. I940).

${ }^{3 x}$ See Matter of Friedman v. Finegan, 268 N.Y. 93, 98, r96 N.E. 755, 756 (1935).

${ }^{2}$ People ex rel. Schau v. McWilliams, 185 N.Y. 92, 99, 77 N.E. 785,787 (rgo6); see People ex rel. Merritt v. Kraft, I45 App. Div. 662, 664, 666, 130 N.Y. Supp. 363, 365, 366 (I9II) ("palpably erroneous").

${ }^{33}$ See Matter of Becker v. Eisner, 277 N.Y. I43, r51, I3 N.E. (2d) 747, $75^{\circ}$ (1938).

34 "There must be something . . . . in the nature of the duties which makes the service either one of confidence or else of such importance that personal selection instead of competitive examination is for the best interests of the public and the fulfillment of the particular duties." Matter of Friedman v. Finegan, 268 N.Y. 93, 98, I96 N.E. 755, 756 (1935). In the Bertrand Russell Case: The History of a Litigation, 53 Harv. L. Rev. Ir92, Ir95 (r940), the writer suggests that the instant court is creating a new standard: "The availability of other persons of equal merit."

${ }^{35}$ See The Bertrand Russell Case: The History of a Litigation, 53 Harv. L. Rev. II92, II95 (I940).

${ }^{36} \mathrm{Cf}$. the affidavit of Ordway Tead, Chairman of the Board of Higher Education, made in a similar suit (note 6I infra), reported in the N.Y. Times, col. 4, p. I (Dec. 28, x940): "Firstclass candidates would not be attracted if they had to enter competitive examinations to secure appointment in such colleges, especially since they could obtain positions in any of the other colleges throughout the country without taking any such examinations."

${ }^{37}$ Matter of Kay v. Board of Higher Education, 173 Misc. 943, 947, 948, 953, I8 N.Y.S. (2d) 82 , $826,827,83$ (S. Ct. I940). 
The conclusion that Russell was immoral was based upon isolated statements taken from four of his books, written eight to fifteen years ago, and upon his alleged personal immorality. The court divided these "exhibits" into two classes, those not mala in se and those considered by the court to be mala in se. The former, Russell's views on masturbation ${ }^{38}$ and nudity, ${ }^{39}$ and his personal conduct, were held to be matters the board must consider, but regarding which its determination was final. The "exhibits" mala in se consisted of those of Russell's opinions which the court found to be in direct conflict with the Penal Law of New York. Because of these latter views of Russell the board's action in appointing him was considered an encouragement to violations of the Penal Law. The court therefore decided that it might intervene.

The court stated that Russell's writings condoning adultery would encourage the commission of a misdemeanor only, but it considered this mitigating argument of no weight in view of Russell's opinions on homosexuality. In Education and the Modern World Russell wrote: "It is possible that homosexual relations with other boys would not be very harmful if they were tolerated, but even then there is danger lest they should interfere with the growth of normal sexual life later on." $4^{\circ}$ It is unlikely that any reasonable person could construe this statement as an encouragement of homosexuality; it is rather a very guarded statement of opinion. The standard adopted by the court would enable judicial removal of any public servant who expressed opinions contrary to any portion of the Penal Law.

Assuming, for discussion, that a court may exercise such power, it would seem only fair that the teacher should have a right to defend himself. Furthermore, the court's opinion virtually condemns itself. That section of the Education Law relied upon to establish a public policy against the appointment of immoral teachers explicitly requires that the teacher against whom a charge affecting his moral character has been brought be given reasonable notice and an opportunity to defend himself. . $^{\mathrm{x}}$

${ }^{38}$ Education and the Good Life 2II (I926): "Left to itself, infantile masturbation has, apparently, no bad effect upon health, and no discoverable bad effect upon character; the bad effects which have been observed in both respects are it seems wholly attributable to attempts to stop it. ... Therefore, difficult as it may be, the child should be let alone in this respect."

39 Education and the Good Life 212 ( 1926$)$ : "A child should, from the first, be allowed to see his parents and brothers and sisters without their clothes whenever it so happens naturally. No fuss should be made either way; he should simply not know that people have feelings about nudity."

40 Education and the Modern World II9 (1932). Nor was it asserted or proved that Russell's statement was not in accord with modern scientific and medical knowledge. Compare the hasty examination of Russell's works by the court in the principal case with the calm, objective approach to a similar problem in United States v. One Book called "Ulysses," 5 F. Supp. I82 (N.Y. 1933), aff'd 72 F. (2d) 705 (C.C.A. 2d 1933).

4 N.Y. Cons. Laws (McKinney, 1938) c. $16, \S 556$. 
II

The denial to Russell of this right and the refusal of the Court of Appeals to act to secure it for him prompts the asking of two questions. Was Russell a party entitled to intervene? Was the order denying his motion seeking the right to intervene an interlocutory or a final order? The Supreme Court found that Russell had no legal status in the proceedings, ${ }^{42}$ presumably on the theory that the petitioner was entitled to proceed against a party of her own choosing. Despite the court's indication that its determination was an exercise of discretion, ${ }^{43}$ in this instance the court, on its own theory, had no discretion. The court assumed that the Board of Higher Education was a body exercising quasijudicial functions. ${ }^{44}$ Where a proceeding is brought against such a body to restrain it from acting in excess of its jurisdiction in favor of another party, the latter must be joined.45 Further, under the New York Civil Practice Act and cases construing it, Russell was an appropriate, if not a necessary, party..$^{6}$ The act requires that persons not parties who have an interest in the subject matter of the action, and who apply to be made parties, be brought in by proper amendment, a requirement which applies to legal as well as equitable actions. ${ }^{47} \mathrm{By}$ express provision it has been made applicable to proceedings under Article $78.4^{8}$

Outsiders in positions analogous to that of Russell have frequently been held

42 See Papers on Appeal from Order in the Matter of Kay v. Board of Higher Education of the City of New York, at 27.

43 Order of Mr. Justice McGeehan, dated April I6, r940.

44 Number twenty-six of the findings of fact, dated April I7, r940.

${ }_{45}$ N.Y. Civ. Prac. Ann. (Gilbert-Bliss, Supp. I940) § x29o.

${ }^{6}$ The distinction between necessary and proper parties was made in White's Bank of Buffalo v. Farthing, roI N.Y. 344, 348, 4 N.E. 734, 735 (I886), an action to set aside certain conveyances of real estate alleged to be fraudulent as to creditors, where the court held that $\$ \mathbf{4 5 2}$ of the Code (now contained in $\S \mathrm{I}_{93}$ (3) of the Civil Practice Act) did not require it to bring in a judgment creditor of the plaintiff having liens on the land in question, since the rights of the creditor not made a party would not be prejudiced by the judgment in the action, and his rights and remedies would remain the same as before. The court distinguished People v. Albany \& V.R. Co., 77 N.Y. 232 ( 1879 ), and Osterhoudt v. Board of Supervisors, 98 N.Y. 239 (1885), where it said "no effectual judgments could be rendered . . . . without directly cutting off or impairing rights of persons not parties. ...." In the Osterhoudt case the court (at p. 244) indicated that the parties not joined were necessary parties and that the court would not proceed without their presence. It follows that when necessary parties apply for intervention, the court must direct that they be brought in. The distinction between "indispensable" and "necessary" parties noted in Clark, Code Pleading ( 1928 ) $\$ 60$, would not apply where the necessary party seeks to intervene, for clearly then he may be brought into court.

47 N.Y. Civ. Prac. Ann. (Gilbert-Bliss, I926) § I93(3). Rosenberg v. Salomon, I44 N.Y. 92, 38 N.E. 982 ( 1894 ), construing $\$ 45^{2}$ of the Code of Civil Procedure, now $\$$ I93(3) of the Civil Practice Act.

${ }^{8}$ N.Y. Civ. Prac. Ann. (Gilbert-Bliss, Supp. 1940$) \S 1306$. 
necessary parties. In a case frequently cited, Osterhoudt v. Board of Supervisors, 49 a taxpayer's suit instituted to vacate audits allegedly illegal and fraudulent was held fatally defective since the parties in whose favor the audits had been made were not joined. In Jenson v. Board of Contract, $5^{\circ}$ a taxpayer's suit to restrain a municipality from entering into an illegal paving contract, the successful bidder was held to be a necessary party. In People v. Albany \& Vermont R. Co., ${ }^{5 \mathrm{x}}$ an action by the attorney general to enforce the forfeiture of the charter of a railway company as to certain unused land, the lessee of that land was held to be necessary to the proceedings. In that case it was emphasized that since the railway might not be unfriendly to a judgment for the petitioner the lessee's interests could not be adequately protected without his presence..$^{2}$ In view of the corporation counsel's refusal to appeal in Russell's case, it is apparent that the philosopher's application for intervention was as urgent as that of the lessee in the Albany Railway case. Furthermore, there are numerous lower court decisions requiring that incumbents be parties to mandamus proceedings seeking their removal.53

Not only is the refusal to permit Russell's intervention a questionable decision, but the holding of the Court of Appeals, without citation of authority, that this denial was not a final order seems doubtful.54 If the disposition of a party's application for intervention is not treated as a final order, the party most interested in the proceedings will be denied an opportunity to appeal to the highest court of the state unless he can obtain permission from the appellate division. Thus the consequence in the Russell case would seem to be that the merits of the controversy can never be reviewed.543 The Court of Appeals has

${ }^{49} 98$ N.Y. 239 (I885). Armstrong v. Fitch, Ir3 App. Div. 3I7, 99 N.Y. Supp. 47 I (Ig06); Daly v. Haight, I $6_{3}$ App. Div. 234, I48 N.Y. Supp. 42 (Igr4). But cf. Hicks v. Cocks, I67 App. Div. 862, I53 N.Y. Supp. 776 (I9 $1_{5}$ ).

${ }^{50} 74$ Misc. 64r, ${ }_{34}$ N.Y. Supp. 630 (S. Ct. Igrr).

${ }^{51} 77$ N.Y. 232 (I879). $\quad 52$ Ibid., at 234-35.

53 People ex rel. Conlin v. Dobbs Ferry, 63 App. Div. 276, 7 I N.Y. Supp. 578 (I9or); People ex rel. Mesick v. Scannell, 63 App. Div. 243, 7 I N.Y. Supp. 383 (I9or); Jones v. Willcox, 80 App. Div. I67, 80 N.Y. Supp. 420 (xg03); People ex rel. Ballou v. Wendell, 57 Hun (N.Y.) 362 , 10 N.Y. Supp. 587 ( 1890 ). Cf. Matter of Bridgman v. Kern, 282 N.Y. 375, 26 N.E. (2d) 299 (1940), where the civil servant sought to be removed was made a party from the beginning. See also Connelly v. Elmira, I44 Misc. 282, 258 N.Y Supp. 603 (S. Ct. I932).

54 In civil cases and proceedings an appeal may be taken to the Court of Appeals from a final judgment or order not appealable as of right "where the appellate division shall certify that in its opinion a question of law is involved which ought to be reviewed by the Court of Appeals, or where, in case of refusal so to certify, an appeal is allowed by the Court of Appeals. Such an appeal shall be allowed when required in the interest of substantial justice. ...." N.Y. Const. art. 6, $\S 7(5)$; N.Y. Civ. Prac. Ann. (Gilbert-Bliss, 1926$) \S 588(5)$. An appeal may be brought to the Court of Appeals from an order or judgment not final where the appellate division allows the same and certifies that a question of law is involved which should be reviewed by the Court of Appeals. N.Y. Const. art. $6, \S 7(4)$; N.Y. Civ. Prac. Ann. (GilbertBliss, I926) $\$ 588$ (4). Compare the discussion in 8 Univ. Chi. L. Rev. II3, 122-23 (1940).

54a The Court of Appeals again refused permission to appeal, apparently putting an end to the case. N. Y. Times, col. 2, p. 36 (Jan. I7, I94I). 
treated as a final order the determination of an application for relief by or against a person not referred to in the original action.ss In analogous situations the test adopted is whether or not the order appealed from puts the appellant out of the case. ${ }^{56}$ If it does, the order is final even though the case had not been finally adjudicated as between the remaining parties. The problem has arisen frequently in partition suits. In a leading case ${ }^{77}$ the court stated categorically that as to the party found not to have any interest in the premises the order was final, although interlocutory as between the parties adjudged to have interest. This principle has been applied elsewhere. In a condemnation proceeding the preliminary determination of the validity of several claims under the same grant, dismissing those claims, was held to be a final order, even though the validity of other claims had not as yet been passed upon..$^{58}$ In a probate proceeding an order ruling that the deceased's widow was not a person interested in the estate was held to be a final order so far as she was concerned.s9

In consequence of the Bertrand Russell litigation, an eminent man, qualified in the subjects he was appointed to teach, ${ }^{60}$ has been deprived of his position and injured in reputation without having had an opportunity to defend himself, and a case bearing directly on the security of tenure of public servants and on broader considerations of academic freedom and civil liberties has been finally disposed of through procedural technicalities. ${ }^{6 x}$ It is an ironic commentary on the efficacy of modern procedure to work substantial justice that consideration of the merits in this case ceased with the lower court opinion of Mr. Justice McGeehan.

ss Rosenberg v. Rosenberg, 259 N.Y. 338, r82 N.E. 8 (r932); Conlon v. Kelly, I99 N.Y. 43, 92 N.E. Iog (I9I0). The court designated such applications special proceedings. Cf. Gang v. Gang, 253 N.Y. 356 , $17 x$ N.E. 568 (1930).

${ }^{56}$ City Bank Farmers Trust Co. v. Ernst, 26I N.Y. 82, 85, I84 N.E. 502, 503 (I933).

57 Brown v. Feek, 204 N.Y. 238, 97 N.E. 526 (r912); Sinclair v. Purdy, 235 N.Y. 245, 139 N.E. 255 (I923); Albany Hospital v. Albany Guardian Society, 214 N.Y. 435, I08 N.E. 8I2 (I9I5); Maggi v. Sabatini, 250 N.Y. 296, 165 N.E. 454 (1929).

${ }^{58}$ Matter of City of New York, 237 N.Y. 275, 142 N.E. 662 (r923).

59 In re Halsted's Estate, 172 Misc. 632, 5 N.Y.S. (2d) 862 (Surr. Ct. 1939).

${ }^{60}$ According to the City College catalogue, Mr. Russell was to teach courses in advanced logic, the philosophy of mathematics, and the relation of philosophy to the sciences. These courses were described as follows: Philo. $13-\mathrm{a}$ study of modern conceptions of logic and of its relation to science, mathematics, and philosophy. Philo. ${ }_{24} \mathrm{~B}-\mathrm{a}$ study of the problems in the foundation of mathematics. Philo. 27-the relations of pure to applied sciences and the reciprocal influence of metaphysics and scientific theories.

6r A "taxpayer's suit" similar to the principal case has recently been instituted in New York seeking the ouster of six teachers at Brooklyn College, one of the city colleges. N.Y. Times, col. 4, p. I (Dec. 28, I940). The petition, based partly on the testimony presented at hearings of the Rapp-Coudert committee, investigating subversive conditions in the New York City schools, asks the removal of the six professors on the ground that they are "communists"; it also denies the legality of their appointments which were made without competitive examinations. The suit is now pending in the lower courts. It is of interest to note that counsel on both sides are the same as in the Russell case. 